\title{
Analysis of temporal leachibility of trace elements to the environment of opoka-rocks used in historical building
}

\author{
Agnieszka Pękala ${ }^{1, *}$, Joanna Hydzik- Wiśniewska ${ }^{2}$ \\ ${ }^{1}$ Rzeszow University of Technology, Faculty of Civil, Environmental Engineering and Architecture, \\ ul. Poznanska 2, 35-959 Rzeszow, Poland \\ ${ }^{2}$ AGH University of Science and Technology, Faculty of Mining and Geoengineering, al. Mickiewicza 30, \\ 30-059 Krakow, Poland
}

\begin{abstract}
The opoka-rock belongs to the silica-carbonate rocks commonly used in historical building. The research material in the form of rock fragments was taken from historical objects located in central Poland in Kazimierz Dolny on the Vistula river. In 8 time fractions according to NEN 7375: 2004 norm, the leachability of the main elements from the beryllium group considered as environmental indicators of building materials enriched with carbonate components was determined. After the application of the ICP sequential plasma-emission spectrometer according to the PN-EN ISO 11885 norm, the concentration of $\mathrm{Ba}, \mathrm{Mg}, \mathrm{Sr}, \mathrm{Zn}, \mathrm{Mn}$ was determined in the water eluates. In addition, physical and mechanical properties such as: open and total porosity, compressive strength in air-dry state, bulk density and specific density; were determined in accordance with the applicable standards. The results of the conducted research allowed finding that the number of leachabilities of the examined elements in decreasing succession were as follows: $\mathrm{Mg}>\mathrm{Sr}>\mathrm{Zn}>\mathrm{Ba}>\mathrm{Mn}$. The highest leachability from the selected elements was found for $\mathrm{Mg}$, which ranged from 0.22 to $1.14 \mathrm{ppm}$.
\end{abstract}

\section{Introduction}

Environmental conditions at the turn of the Mesozoic and Cenozoic left rocks with inhomogeneous petrographic composition, transitional rocks with a silica-carbonate character described in this study as opoka-rocks. In Poland, these sediments occur in the vast areas of the Lublin Upland, in the Mielno-Łódź Basin and the Nidzica Basin. They include a lithostratigraphic profile from Turonian to Maastrichtian. Diversified conditions of their formation caused the variability of the varieties being formed. Besides calcium opoka-rocks, there are calcareous and decalcified opoka-rocks (light rock) found with different characteristics and chemical compositions [table 1]. In research works, it was found opoka-rocks covered by secondary mineralization processes that resulted in the formation of silificated opoka-rocks [1].

*Corresponding author: apekala@prz.edu.pl 
Table 1. Classification of rocks depending on the percentage of silica and carbonates [1,2].

\begin{tabular}{|c|c|c|}
\hline \multirow{2}{*}{ Rock name } & \multicolumn{2}{|c|}{ Chemical component [wt.\%] } \\
\cline { 2 - 3 } & $\mathbf{S i O}_{2}$ & $\mathbf{C a O}$ \\
\hline $\begin{array}{c}\text { Calcium opoka-rock } \\
\text {,,heavy” opoka) }^{[2]}\end{array}$ & $5-25$ & $53.2-42$ \\
\hline Calcareous opoka-rock $^{[2]}$ & $25-50$ & $42-28$ \\
\hline $\begin{array}{c}\text { Decalcified opoka-rock } \\
\text { "light" opoka }^{[2]}\end{array}$ & $50-75$ & $28-14$ \\
\hline Silificated opoka-rock $^{[1]}$ & $40.2-66$ & $16-30.5$ \\
\hline
\end{tabular}

\subsection{Application of the opoka-rocks in historical building}

The use of the opoka-rocks as a building material is known from the ancient history of Poland. This raw material from the Paleolithic through the Middle Ages to the present day is an important stone raw material in southern Poland, mainly in the Świętokrzyskie and Lubelskie regions. Easy access to this stone and ease of mining were reflected in the regional sacral, defense and residential construction of these areas. Its largest use falls on the time interval from the 16th to the 19th century. Palaces, mansions, churches, walls, and architectural elements were built from the opoka-rock, and they were used in residential and commercial construction. There are many examples. The most famous are the objects from Kazimierz Dolny on the Vistula river, and among them is the oldest monument of the city from the 13th century, the Kazimierz tower, the castle in Kazimierz, the synagogue from the eighteenth century and the foundations of local buildings.

\subsection{The research purpose}

As part of studies on building materials, chemical analyses were carried out to determine the leachability of trace elements from stones made of the opoka-rock. In previous studies, it was found that in the opoka-rocks the highest concentration of elements reached were such elements as: strontium, bar, zinc, manganese [3]. In the literature, however, there are no studies considering the influence of time and water on the release of trace elements from the stone materials to the environment. Therefore, in order to characterize the opoka-rocks constituting the building material, it was attempted to determine:

- structural-textural features and mineralogical composition;

- physico-mechanical parameters that determine this application;

- leachability of the trace elements to the environment at specific time intervals.

The nature of the carried out mineralogical and chemical research is mainly a cognitive part of the time appraisal of the impact of building materials on the environment. Determination of the physico-mechanical properties complements the characteristics of the examined stone in the building aspect. 


\section{Research material and methodology}

The research material that formed the basis of the analysis came from the vicinity of Kazimierz Dolny from a demolished house in Bochotnica. According to information from the house users, it was most probably created at the turn of the 19th and 20th centuries. The material collected for research was represented by irregular rock fragments that were macroscopically characterized by a light cream - white color. Rusty discolorations were visible in some places on the rock surface. The traces of bioclasts were the only recognizable macroscopic elements in the rock. The texture of the opoka-rocks was porous and disorganized. Material for chemical and physical-mechanical tests was separated from the collected samples, which was prepared according to valid standards. In order to determine the leachability of $\mathrm{Sr}, \mathrm{Mn}, \mathrm{Mg}, \mathrm{Ba}, \mathrm{Zn}$, water extracts were made according to the NEN 7375: 2004 standard [4]. The mineralization of water eluates was prepared according to the EN ISO 11885 standard [5]. The tests were carried out for 8 time fractions in which, using the ICP Ultima 2 Horiba Jobin Yvon sequential plasma-emission spectrometer, these elements were determined. The main components of the studied opokarocks $\left(\mathrm{SiO}_{2}, \mathrm{CaO}, \mathrm{Al}_{2} \mathrm{O}_{3}, \mathrm{Fe}_{2} \mathrm{O}_{3}, \mathrm{MgO}, \mathrm{MnO}, \mathrm{P}_{2} \mathrm{O}_{5}, \mathrm{~K}_{2} \mathrm{O}, \mathrm{TiO}_{2}\right)$ were determined by X-ray fluorescence (XRF). In addition, as part of research using microscopes: a digital microscope Hirox- $\mathrm{RH}-2000-\mathrm{EN}$, a polarizing microscope Olympus BX-51 and an electron microscope (SEM) FEI Quanta 200FEG equipped with an X-ray spectrometer (EDX Genesis) and backscattered electron detector (BSE), were used to determine the mineral, structural and textural features of the studied rocks. The geomechanical parameters were determined in accordance with existing standards. The following were determined: compressive strength in an air-dried state (PN-EN 1926: 2001) [6]; open and total porosity (PN-EN 1936: 2001); density and apparent density (PN-EN 1936: 2001) [7].

\section{Research results}

The results of tests on chemical composition of the opoka-rocks, determined for 18 samples are given in Table 2. The dominant components are $\mathrm{SiO}_{2}$ and $\mathrm{CaO}$. The content of both these components confirms the transitional character of the studied rocks, with the average value of silica being around $33 \mathrm{wt} . \%$ and carbonates $30 \mathrm{wt} . \%$. In addition, the presence of $\mathrm{Al}_{2} \mathrm{O}_{3}$ was found at an average value of 3.15 wt. $\%, \mathrm{Fe}_{2} \mathrm{O}_{3}$ with an average concentration of $1.63 \mathrm{wt} . \%$. and $\mathrm{MgO}$ with an average value of $1.45 \mathrm{wt} . \%$. The remaining components occur in minor quantities.

Microscopic observations in polarized light have shown that the structure of the studied opoka-rocks is micrite - organogenous. The rocky background is primarily composed of a carbonate substance formed as micrite (Fig.1). There are also visible clusters of amorphous silica that are formed as opal A and CT. In the rocky mass, there are numerous carbonate bioclasts, represented mainly by the shells of foraminifers, fragments of echinoderms and molluscs. Silica sponges are also found. In the rocky background instead of the bioclasts, among the detritic material, there were also quartz grains found from pelite to aleurite fraction. In addition, glauconite grains and hydromuscovite plaque are visible.

Automorphic pyrite crystals and heavy minerals were found in accessories. Rock surface analysis in 3D using the Hirox - RH - 2000-EN microscope confirms the highly porous nature of the studied rocks. The pores take different shapes from oval to irregular, but do not constitute interconnected networks. The porosity coefficient determined for the fragment of the rock surface was almost 10\% (Fig.2). 


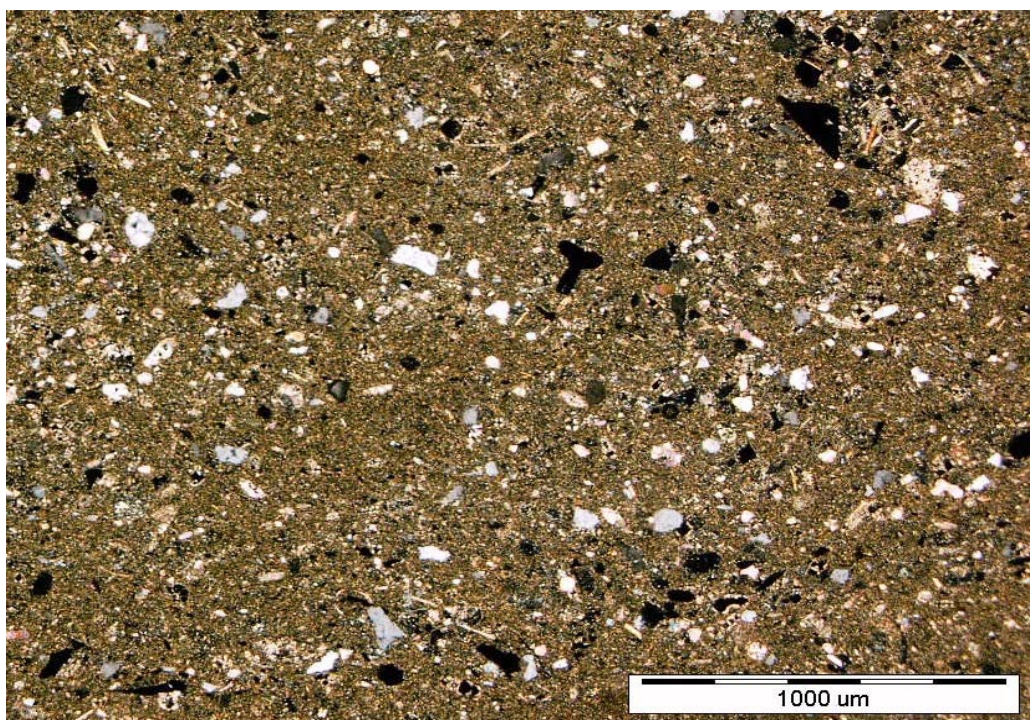

Fig. 1. Image of the micrite background of the opoka-rock with silica-carbonate material. Observation - polarization microscope $2 \mathrm{P}$ (own study).

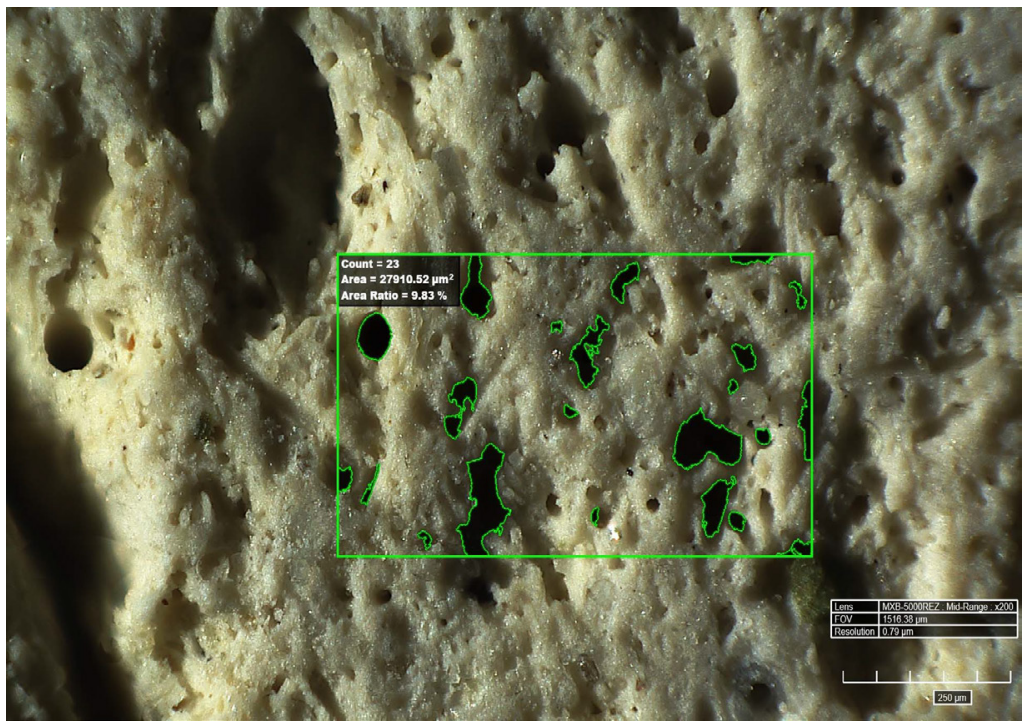

Fig. 2. Image of a porous texture of the opoka-rock with exemplary porosity coefficient for a rock surface (own study).

Geomechanical studies of the Kazimierz opoka-rocks showed that the average open porosity value was $28.71 \%$ and the total porosity was $32.34 \%$ (Table 2 ). These results are lower than they are reported in the literature. According to Kozłowski, the value of porosity for the opoka-rocks from the Kazimierz region is 46.4\% [2]. The average values of the strength parameter in the air-dried state were $38.18 \mathrm{MPa}$, which positions these rocks to be much more durable than the data from the literature is in the range of 10-30 MPa [8]. Apparent density results ranging from 1.6 to $1.8 \mathrm{~g} / \mathrm{cm}^{3}$ prove that the studied opoka-rocks belong to light and very light rocks. 
Table 2. Research results of the Kazimierz opoka-rocks (own study).

\begin{tabular}{|c|c|c|}
\hline Parameter & Average value & Change range of parameter \\
\hline \multicolumn{3}{|c|}{ chemical [wt.\% ] } \\
\hline $\mathrm{SiO}_{2}$ & 32.82 & $18.73-42.50$ \\
$\mathrm{CaO}$ & 30.47 & $21.94-33.13$ \\
$\mathrm{Al}_{2} \mathrm{O}_{3}$ & 3.15 & $2.28-5.92$ \\
$\mathrm{Fe}_{2} \mathrm{O}_{3}$ & 1.63 & $0.67-2.55$ \\
$\mathrm{MgO}$ & 1.45 & $0.53-2.90$ \\
$\mathrm{MnO}$ & 0.02 & $0.01-0.03$ \\
$\mathrm{Na}{ }_{2} \mathrm{O}$ & 0.02 & $0.03-0.04$ \\
$\mathrm{P}_{2} \mathrm{O}_{5}$ & 0.03 & $0.01-0.05$ \\
$\mathrm{~K}_{2} \mathrm{O}$ & 0.05 & $0.02-0.09$ \\
$\mathrm{TiO}_{2}$ & 0.02 & $0.01-0.04$ \\
\hline \multicolumn{2}{|c|}{ physico-mechanical } \\
\hline Density [g/cm $\left.{ }^{3}\right]$ & 2.54 & $2.53-2.55$ \\
Apparent density [g/cm $\left.{ }^{3}\right]$ & 1.74 & $1.68-1.81$ \\
Compressive strength $[\mathrm{MPa}]$ & 38.18 & $16.98-60.32$ \\
Open porosity [\%] & 28.71 & $26.46-30.87$ \\
Total porosity [\%] & 32.34 & $29.09-35.34$ \\
\hline
\end{tabular}

The carried out tests of the leachability of elements from the opoka-rocks showed that all of the selected elements penetrate into the aquatic environment. The highest concentrations were recorded for $\mathrm{Mg}$, the maximum value of which after 9 days of leaching amounted to $1.14 \mathrm{mg} / \mathrm{l}$. The concentration of magnesium in the first sample after $6 \mathrm{~h}$ shows a concentration of many times higher, ie $0.22 \mathrm{mg} / \mathrm{l}$ more than the values obtained for other elements (table 3). Over time, the concentration of this element decreases gradually reaching in the last test after $1,536 \mathrm{~h}$ the value of $0.84 \mathrm{mg} / \mathrm{l}$. On this basis, it can be assumed that further leaching tests for this element would show a downward trend. From the analysed elements, the lowest concentration in aqueous eluates was recorded for manganese. The leachibility of this element was noticed until after $24 \mathrm{~h}$ and took the value of $0.001 \mathrm{mg} / \mathrm{l}$. Its maximum value after $96 \mathrm{~h}$ is $0.01 \mathrm{mg} / \mathrm{l}$, with manganese being the only one from the analysed elements after $384 \mathrm{~h}$ to reach the final result of the transition to the solution, the last two samples were below the limit of determination. Analysing the results obtained for zinc, it is difficult to indicate the leading trend in the obtained results. The concentration of this element in the eluates ranges from $0.16 \mathrm{mg} / 1$ to $0.02 \mathrm{mg} / \mathrm{l}$. The maximum value was reached after 24 hours and further results show a downward trend to the minimum value achieved after 1,536 h (64 days). Strontium is noteworthy from the analysed elements, its concentration in individual fractions oscillates between the values of $0.04-0.28 \mathrm{mg} / \mathrm{l}$ and is in terms of the amount penetration of this element second after magnesium. The nature of strontium leaching to the water environment in the first hours of research shows an increasing trend (Fig.3). Its concentration increases uniformly until $384 \mathrm{~h}$ reaching a maximum value of $0.28 \mathrm{mg} / \mathrm{l}$. After a period of 16 days, its concentration gradually began to decrease. The last of the obtained results did not indicate a downward trend. The leachability of $\mathrm{Ba}$ from the beginning to the end of the carried out tests was uniform and during all research periods oscillates at the value of $0.02 \mathrm{mg} / \mathrm{l}$. 
Table 3. The content of the trace elements in water eluates obtained at different time periods (own study).

\begin{tabular}{|c|c|c|c|c|c|c|c|c|}
\hline \multirow{2}{*}{$\begin{array}{c}\text { Element } \\
{[\mathbf{m g} / \mathbf{l}]}\end{array}$} & \multicolumn{10}{|c|}{ Temporal leachibility $\mathbf{t}[\mathbf{h}]$} \\
\cline { 2 - 10 } & $\mathbf{6}$ & $\mathbf{2 4}$ & $\mathbf{5 4}$ & $\mathbf{9 6}$ & $\mathbf{2 1 6}$ & $\mathbf{3 8 4}$ & $\mathbf{8 6 4}$ & $\mathbf{1 5 3 6}$ \\
\hline $\mathrm{Sr}$ & 0.04 & 0.12 & 0.16 & 0.20 & 0.26 & 0.28 & 0.24 & 0.24 \\
\hline $\mathrm{Ba}$ & 0.02 & 0.02 & 0.02 & 0.02 & 0.02 & 0.02 & 0.02 & 0.02 \\
\hline $\mathrm{Mn}$ & 0 & 0.001 & 0.002 & 0.01 & 0.01 & 0.001 & b.d.1 & b.d.1 \\
\hline $\mathrm{Mg}$ & 0.22 & 1.12 & 1.06 & 0.90 & 1.14 & 1.04 & 0.94 & 0.84 \\
\hline $\mathrm{Zn}$ & 0.06 & 0.16 & 0.04 & 0.06 & 0.06 & 0.04 & 0.06 & 0.02 \\
\hline
\end{tabular}

b.d.1-below determination limit

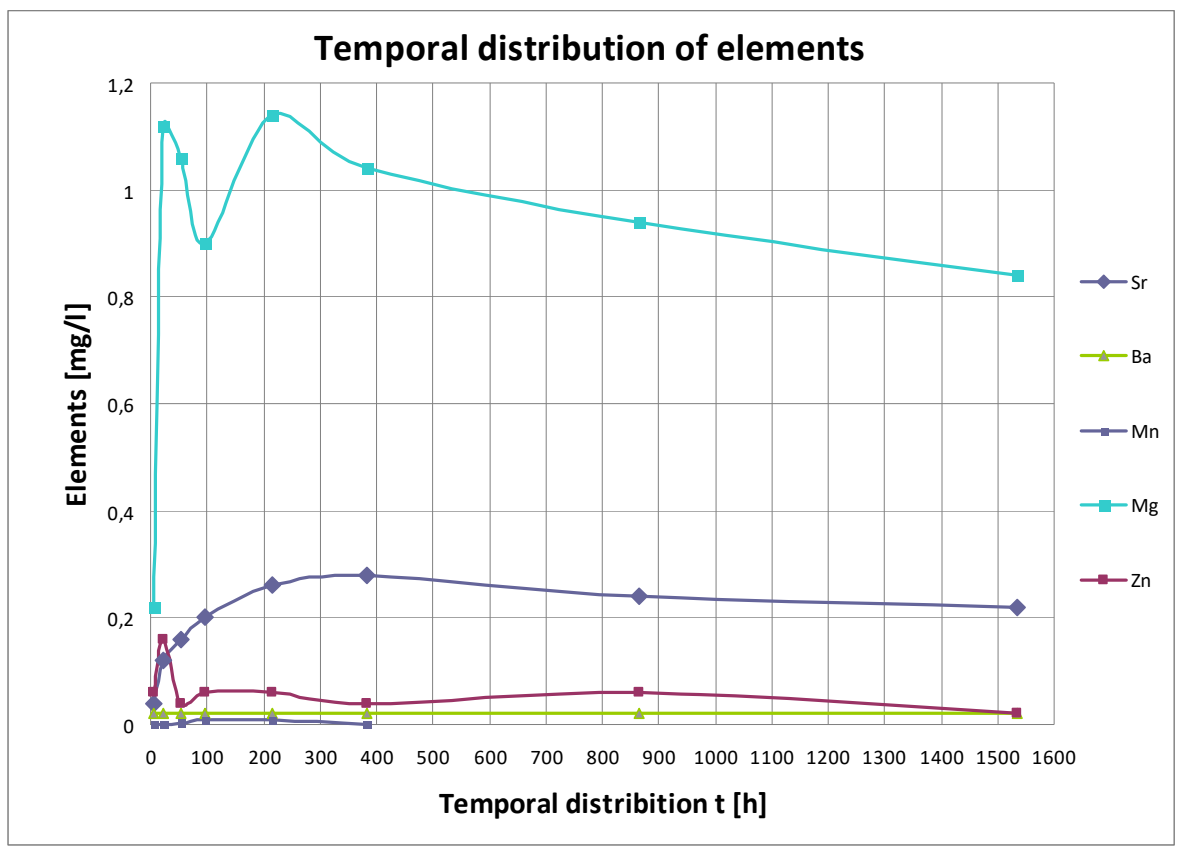

Fig. 3. Graph of the test of temporal leachability of the trace elements from the Kazimierz opoka-rocks (own study).

\section{Conclusion}

The carried out leaching tests for the trace elements such as $\mathrm{Sr}, \mathrm{Mg}, \mathrm{Mn}, \mathrm{Zn}$ and $\mathrm{Ba}$ from the opoka-rocks showed that all of the analysed elements were leached into the aquatic environment. A series of leachability for the studied elements in the ascending order was $\mathrm{Mg}>\mathrm{Sr}>\mathrm{Zn}>\mathrm{Ba}>\mathrm{Mn}$. The highest concentration in water eluates has been reached by magnesium at a maximum value of $1.14 \mathrm{mg} / \mathrm{l}$. This and other results, however, do not exceed the permissible values of trace elements in the waters specified in the Ministries Regulations $[9,10]$. In the analysed case, geomechanical studies have shown that time has an impact on the reduction of porosity of the studied rocks and thus improves their mechanical properties. The increase of values of the strength parameters may be related to the time which affects the change of not only structural-textural but also chemical features. The research shows that the opoka-rocks are rocks that require seasoning as a result of which their strength parameters are improved. 
In the next research work, the authors will focus on mineralogical and petrographic issues in the aspect of detailed analysis of variability of structural and textural features and mineralogical transformations of components present in the rock in terms of water impact and time differences.

\section{References}

1. A. Pękala, Arch Civ Eng. 61, 4 (2015)

2. S. Kozłowski, Wyd. Geol., Warszawa (1986)

3. A. Pękala, GiG. 7, 2: 187-205 (2012)

4. EA NEN 7375:2004 Leaching characteristics of moulded or monolithic building and waste materials. Determination of leaching of inorganic components with the diffusion test. The Tank Test.

5. EN ISO 11885 Water quality - Determination of selected elements by inductively coupled plasma optical emission spectrometry (ICP - OES)

6. PN-EN 1926:2001. Metody badań kamienia naturalnego. Oznaczenie wytrzymałości na ściskanie w stanie powietrzno-suchym (Polish Standard. Methods of test for natural stone. Determination of compressive strength in the air-dried state)

7. PN-EN 1936:2001. Metody badań kamienia naturalnego. Oznaczanie gestości objętościowej oraz całkowitej i otwartej porowatości (Polish Standard. Methods of test for natural stone. Determination of bulk density, total and open porosity).

8. J. Pinińska, A. Bobrowska, D. Łukasik, Studia Quaternaria, 33, 2 (2016)

9. Regulation of the Minister of Health of 13 November 2015 on the quality of water for human consumption

10. Regulation of the Minister of Environmental Protection of 11 February 2004 on classification for presenting the state of surface water and groundwater 